\title{
GAMBARAN PROSES GRIEVING PADA DEWASA AWAL YANG MENGALAMI KEHILANGAN ANGGOTA KELUARGA AKIBAT VIRUS COVID-19
}

\author{
Adelia Dwiartyani $^{1}$, Aliah B. Purwakania Hasan ${ }^{2}$, Hanifah Arief ${ }^{3}$ \\ E-mail:aliah@uai.ac.id
}

Prodi Psikologi, Fakultas Psikologi dan Pendidikan, Universitas Al Azhar Indonesia, Jl. Sisingamangaraja, Selong, Kebayoran Baru, Jakarta Selatan, Daerah Khusus Ibukota Jakarta, 12110

\begin{abstract}
The COVID-19 Pandemic has been taking many lives and left the world with major grieves. In early adults, they tend to face an intense and prolonged grieving process. The purpose of this research is to determine an overview of grieving process in early adulthood who lost family member due to COVID-19 virus. This research uses the Worden Four Task of Mourning theory. The subjects for this research are 3 females' (22-23 years old) early adult who lost family member due to COVID-19 virus. The method of this study is qualitative phenomenology and using observation and depth interview as the techniques. The result of this research indicate that all three subjects are able to complete the Four Task of Mourning in their own way despite being in the pandemic era where they're not able to communicate directly with their loved one, not able to watch funeral of the deceased, not able to be with the deceased during their last time, even got another misfortune such as dealing with another family member who is tested positive for COVID-19 virus or lost another parent a week after the loss of the other parent. These subjects are able to get through their grieving process because of several things. The things that help them get through their grieving process are there are believe and willingness in themself, get close to Allah, also have job that displacing their sadness.
\end{abstract}

Keyword: grieving, COVID-19, early adulthood

\begin{abstract}
Abstrak
Pandemi COVID-19 telah merenggut banyak jiwa dan meninggalkan dunia dengan duka atau grieving yang besar. Pada dewasa awal cenderung menghadapi proses grieving yang intens dan berkepanjangan. Penelitian ini bertujuan untuk mengetahui gambaran proses grieving pada dewasa awal yang mengalami kehilangan anggota keluarga akibat virus COVID-19. Penelitian ini menggunakan teori empat tugas proses grieving yang dikemukakan oleh William Worden. Subjek penelitian ini berjumlah 3 orang wanita yang merupakan dewasa awal yang berusia 22-23 tahun yang mengalami kehilangan anggota keluarga akibat virus COVID-19. Penelitian ini menggunakan metode kualitatif fenomenologi, dengan teknik pengambilan data observasi dan wawancara mendalam. Hasil dari penelitian ini menunjukkan bahwa ketiga subjek mampu menyelesaikan empat tugas proses grieving dengan cara yang berbeda walaupun berada di era pandemi dimana tidak bisa berkomunikasi dengan
\end{abstract}


langsung dengan orang-orang terdekat, tidak dapat menyaksikan pemakaman almarhum, tidak dapat mendampingi almarhum pada terakhir kalinya, bahkan terkena musibah lain seperti anggota keluarga lain juga terkena COVID atau ayah meninggal seminggu setelah ibu meninggal terkena COVID. Para subjek mampu melewati proses grieving karena beberapa hal yaitu adanya keyakinan dan kemauan yang terdapat dari diri sendiri, mendekatkan diri kepada Allah SWT, serta memiliki pekerjaan yang membantu mengalihkan fokus mereka atas kesedihannya.

Kata kunci: grieving, COVID-19, dewasa awal

\section{PENDAHULUAN}

Pada Maret 2020 World Health Organization (WHO) menyatakan COVID-19 sebagai pandemi setelah terdapat 200 ribu pasien dengan 8000 kematian pada lebih dari 160 negara. Sohrabi menyatakan bahwa pandemi COVID-19 menyebabkan berbagai dampak terhadap kehidupan manusia. Pandemi COVID-19 memiliki dampak yang sangat drastis terhadap kesejahteraan sosieomosional dan fisik miliaran orang (Singer,2020). Dampak tersebut terjadi akibat jumlah kematian yang sangat banyak akibat virus COVID-19.

Biasanya seseorang membutuhkan waktu selama 6 sampai 12 bulan untuk beradaptasi setelah kematian orang yang dia sayangi, dan pada akhirnya ia akan mengembangkan rasa normal yang baru dalam kehidupannya. Ketika seseorang menghadapi peristiwa kematian anggota keluarganya atau kerabat dekatnya yang ia sayangi, biasanya ia akan melakukan ritual pemakaman, atau menemani pada detikdetik terakhir yang sudah tiada, sebagai tanda perpisahan untuk terakhir kalinya. Namun, dikarenakan terdapat pandemi COVID-19, maka hal-hal yang biasa dilakukan untuk menghormati orang yang sudah tiada tidak dapat dilakukan atau terhambat.

Pandemi COVID-19 bukan hanya menyebabkan penyakit bagi penderitanya namun juga memberikan dampak bagi sosioemosional yang drastis bagi masyarakat dalam berbagai usia, tidak terkecuali pada dewasa awal. Balk dan Vesta (1998) menyatakan bahwa, kelompok dewasa awal (18-25 tahun) mengalami respons yang bermasalah terhadap kehilangan lebih sering daripada yang diketahui. Pada kelompok usia ini berhubungan dengan kesulitan akademis, dan dapat berdampak pada perkembangan, okupasi, dan tugas sosial yang berkaitan dengan masa dewasa awal. Brent menyatakan, faktanya, dewasa awal yang berduka lebih sering mengalami duka yang yang intens dan berkepanjangan, penurunan kesehatan, peningkatan kunjungan dokter untuk masalah fisik dan emosional, dan peningkatan penggunaan narkoba, alkohol, setelah mengalami kehilangan (Mash, 2015).

Peneliti melakukan wawancara singkat dengan tiga dewasa awal (22-23 tahun) yang mengalami kehilangan anggota keluarga akibat terpapar virus COVID-19 bulan Desember 2020 melalui daring video-call. Salah satu dewasa awal menunjukkan bahwa ia masih merasa sedih selama beberapa bulan terakhir. Dewasa awal tersebut menceritakan mengenai kejadian meninggalnya salah satu orangtuanya sambil meneteskan air mata. Dari hasil data yang didapat peneliti melalui wawancara dengan dewasa awal yang berduka akibat kematian anggota keluarga karena virus 
COVID-19, hal ini melatarbelakangi peneliti untuk meneliti mengenai gambaran proses grieving pada dewasa awal.

Gambaran proses grieving ini akan dipahami melalui salah satu konsep grieving yang dikemukakan oleh Worden yaitu "Empat Tugas dalam Proses Berduka". Teori Worden menyediakan penjelasan bahwa orang yang berduka membuat beragam adaptasi terhadap kehilangan seseorang yang dicintai. Beberapa membuat adaptasi yang lebih baik, beberapa ada yang kurang baik. Walaupun tugastugas tersebut tidak perlu dilakukan secara berurutan, namun ada beberapa urutan yang disarankan dalam definisi tersebut (Worden, 2018).

Banyak penelitian yang telah membahas mengenai ini, namun masih sedikit penelitian yang membahas membahas mengenai bagaimana gambaran grieving pada dewasa awal yang menghadapi peristiwa kematian anggota keluarganya akibat virus COVID-19, tidak seperti situasi biasanya dimana orang-orang dapat melakukan ritual-ritual sebagai ucapan perpisahan, pandemi ini menyebabkan isolasi pada manusia. Berdasarkan hal tersebut, maka peneliti tertarik untuk mengetahui bagaimana gambaran proses grieving pada dewasa awal yang kehilangan anggota keluarganya akibat virus COVID-19.

\section{KERANGKA TEORITIS}

Menurut Freud, grieving merupakan reaksi natural dan alamiah terhadap kehilangan seseorang yang disayangi (Prigerson, 2021). Grieving merupakan emosi rumit yang melibatkan cara untuk menjaga memori orang yang telah tiada tetap hidup dan pada hal lain untuk menghadapi kenyataan atas kehilangan (Overvad \& Wagoner, 2019). Definisi lain mengenai grieving adalah respons insting psikologis yang umum terhadap pengalaman kehilangan seseorang yang disayang (Shear, 2012). Dari beberapa definisi yang telah disampaikan oleh para ahli, maka grieving merupakan respons yang muncul akibat seorang individu mengalami suatu kehilangan. Respons ini muncul dapat berbagai bentuk perasaan negatif seperti kesedihan, amarah ataupun kesepian.

Menurut Worden (2018), terdapat 4 Tugas dalam Proses grief, tugas-tugas ini harus diselesaikan selama proses berduka.

\section{Tugas 1: Untuk Menerima Kenyataan atas Kehilangan}

Ketika seseorang meninggal, walaupun kematian telah diprediksi, tetap saja selalu ada perasaan dimana hal itu tidak terjadi. Tugas pertama dalam berduka adalah menghadapi realita secara keseluruhan bahwa seseorang tersebut sudah tiada, bahwa orang tersebut sudah pergi dan tidak akan kembali. Bagian penerimaan dalam realita ini adalah mulai percaya bahwa reuni adalah sesuatu yang mustahil, setidaknya di kehidupan ini. Banyak orang yang mengalami kehilangan, terkadang salah mengidentifikasi orang yang berada di lingkungannya, orang tersebut mengira bahwa seseorang yang ia lihat merupakan kerabatnya yang sudah meninggal. Mereka mungkin sedang berjalan di jalan, dan melihat sepintas seseorang yang mengingatkannya terhadap kerabat yang sudah meninggal itu dan harus mengingatkan diri sendiri bahwa orang yang mereka lihat di jalan adalah orang lain, bukan kerabat mereka yang sudah meninggal. 
Lawan dari menerima kenyataan terhadap kehilangan adalah tidak percaya melalui tipe penyangkalan. Beberapa orang menolak percaya bahwa kematian adalah benar adanya dan tertahan pada tugas pertama. Cara lain manusia melindungi diri sendiri dari realita adalah menyangkal makna dari kehilangan. Dengan cara seperti ini, kehilangan menjadi seperti kurang signifikan daripada yang seharusnya. Pernyataan yang sering didengar seperti "Dia bukan ayah yang baik", "kami tidak dekat", atau "saya tidak merindukannya". Menghapus semua hal yang mengingatkan hal yang berkaitan dengan almarhum meminimalisir rasa kehilangan (Worden, 2018).

Worden menyadari bahwa menerima kenyataan atas kehilangan membutuhkan waktu dan tidak hanya fungsi kognitif yang sederhana karena juga membutuhkan penerimaan emosional. Menerima kenyataan atas kehilangan membutuhkan dukungan tambahan seperti melihat jenazah, menghadiri pemakaman, berbagi mimpi, dan juga memanfaatkan pengalihan yang sehat (Shear, 2012).

\section{Tugas 2: Untuk Mengatasi Rasa Sakit dan Kesedihan}

Pada saat berduka, penting untuk mengakui dan mengatasi rasa sakit. Tidak semua orang merasakan rasa sakit yang sama, namun hampir mustahil kehilangan seseorangan yang sangat lekat dengan diri seseorang tanpa mengalami beberapa tingkat rasa sakit. Orang yang baru berduka sering tidak siap dalam menghadapi paksaan dan emosi alamiah yang berkaitan dengan kehilangan. Beberapa orang tidak mau merasakan rasa sakit dari duka dan berusaha untuk mencari cara untuk menghindarinya. Beberapa orang mencari cara untuk menghindarinya dengan melakukan liburan ke tempat-tempat yang dapat meringankan emosinya, beberapa orang lain melakukan stimulasi dengan cara memikirkan hanya waktu-waktu yang menyenangkan dengan almarhum.

Ketika tugas kedua tidak dilakukan dengan baik, terapi mungkin perlu dilakukan karena akan ada waktu dimana seseorang akan kembali untuk merasakan rasa sakit yang selama ini mereka hindari. Pada saat tersebut datang, biasanya pengalaman tersebut akan lebih sulit untuk dihadapi daripada menghadapinya pada waktu kehilangan (Worden, 2018).

\section{Tugas 3: Untuk Beradaptasi Pada Lingkungan Baru}

Terdapat 3 area penyesuaian yang perlu dibahas setelah kehilangan orang disayang karena kematian. Tiga area tersebut yaitu, penyesuaian eksternal atau bagaimana kematian memengaruhi fungsi keseharian individu tersebut pada dunia, penyesuaian internal atau bagaimana kematian memengaruhi kesadaran diri individu, dan penyesuaian spiritual atau bagaimana kematian memengaruhi kepercayaan, nilai, dan asumsi individu terhadap dunia (Worden, 2018).

Beradaptasi pada lingkungan yang baru tanpa almarhum memiliki makna yang berbeda bagi setiap orang, tergantung dengan bagaimana hubungan almarhum dengan orang yang berduka. Membutuhkan beberapa periode waktu untuk menyadarkan orang yang berduka bagaimana rasanya hidup tanpa almarhum. Kesadaran ini biasanya terjadi saat tiga sampai empat bulan setelah kepergian almarhum (Worden, 2018). 
Kepergian almarhum dapat membuat sebuah rintangan bagi orang yang berduka dalam beradaptasi dengan dirinya sendiri. Kematian dapat memengaruhi definisi diri, harga diri, dan efikasi diri. Terdapat beberapa hubungan yang membuat rasa harga diri seseorang bergantung pada orang yang memiliki kelekatan dengan dirinya. Beberapa berpikir bahwa hal ini sebagai kelekatan yang aman. Ketika terdapat kelekatan dan orang tersebut meninggal, maka orang yang berduka mungkin menderita kerusakan yang parah bagi harga dirinya. Terutama jika almarhum membangun perkembangan defisit yang serius bagi orang yang berduka.

Menurut Holowit et al., proses grieving juga dapat memengaruhi efikasi diri seseorang (sejauh mana seseorang dapat merasakan bahwa mereka memiliki kendali atas apa yang terjadi kepada mereka). Hal ini dapat menimbulkan regresi yang intens, dimana orang yang berduka merasa tidak berdaya, tidak akuat, tidak mampu, kekanak-kanakan dan bangkrut. Attig (2011) menekankan pentingnya untuk mempelajari kembali dunia setelah kematian seseorang dan fokus terutama pada dampak kematian orang tersebut terhadap diri sendiri orang tersebut.

\section{Tugas 4: Untuk Mencari dan Mempertahankan Hubungan dengan Almarhum Selagi Maju Terus dalam Kehidupan}

Tugas keempat dalam proses berduka yaitu untuk mencari cara mengingat almarhum selagi memulai perjalanan sisa kehidupan individu tersebut. Volkan (1985) menyatakan bahwa masa berkabung berakhir pada saat yang berduka tidak lagi membutuhkan untuk mengaktifkan kembali representasi almarhum dengan intensitas yang berlebihan dalam kehidupan sehari-hari. Tugas konselor pada tugas keempat adalah membantu yang berduka dalam mencari tempat yang sesuai untuk alhmarhum tinggal dalam kehidupan emosionalnya, sebuah tempat yang mengizinkan bagi yang berduka untuk bisa melanjutkan hidup secara efektif di dunia (Worden, 2018).

Menurut Worden terdapat beberapa mediator yang berkemungkinan mempengaruhi proses grief, di antaranya (Tanacioglu, 2019) :

a. Siapa orang yang meninggal.

b. Kelekatan.

c. Bagaimana orang tersebut meninggal .

d. Riwayat kehilangan orang yang berduka, dan bagaimana cara berdukanya, atau riwayat kesehatan mental yang berduka .

e. Variabel Kepribadian : usia, gender, tipe koping, tipe kelekatan, tipe kognitif, kekuatan ego yang berduka, nilai dan kepercayaan adalah faktor kepribadian yang mempengaruhi proses grief.

f. Variabel Sosial : bagi orang yang berduka dukungan sosial sangat penting dalam hal kepuasan pelayat dari dukungan itu, keterlibatan peran sosial dari orang yang berduka (ditemukan bahwa keterlibatan yang berduka dalam beberapa peran dapat menjadikan adaptasi terhadap kehilangan lebih baik), ekspektasi religius dan etnis yang berduka.

g. Stressor Konkuren: Faktor stress yang berturut-turut datang dalam kehidupan yang berduka dapat memberikan dampak bagi kehilangan. 


\section{METODE PENELITIAN}

Pendekatan yang digunakan dalam penelitian ini merupakan pendekatan kualitatif. Jenis penelitian yang digunakan pada penelitian ini adalah perspektif fenomenologi. Penelitian ini berlangsung dari Desember 2020 hingga selesai. Lokasi penelitian dilakukan menyesuaikan dengan subjek. Pada era pandemi COVID-19 diberlakukan sistem jaga jarak untuk mencegah penyebarluasan virus COVID-19, sehingga aktivitas penelitian dilakukan secara daring dengan menggunakan aplikasi video-call untuk melakukan observasi dan wawancara. Teknik sampling yang digunakan dalam penelitian ini merupakan non-probability purposive sampling.

Kriteria subjek pada penelitian ini agar batasan penelitian menjadi lebih jelas adalah:

1. Subjek merupakan dewasa awal (18 - 40 tahun) karena pada penelitian ini memiliki fokus pada bagaimana proses grieving pada dewasa awal.

2. Subjek merupakan seseorang yang mengalami kehilangan anggota keluarga di era pandemi COVID-19 akibat terkena virus COVID-19.

Tabel 1. Karakteristik Subjek

\begin{tabular}{|l|c|c|c|}
\hline \multicolumn{1}{|c|}{ Identitas } & Subjek 1 & Subjek 2 & Subjek 3 \\
\hline Inisial & NA & KT & CT \\
\hline Jenis Kelamin & Perempuan & Perempuan & Perempuan \\
\hline Tempat, Tanggal Lahir & $\begin{array}{c}\text { Jakarta, 11 } \\
\text { September 1998 }\end{array}$ & $\begin{array}{c}\text { Jakarta, 18 Januari } \\
1998\end{array}$ & $\begin{array}{c}\text { Jakarta, 13 Februari } \\
1998\end{array}$ \\
\hline Usia & 22 tahun & 23 tahun & 23 tahun \\
\hline Kedudukan dalam Keluarga & $\begin{array}{c}\text { Anak ke 7 dari 7 } \\
\text { bersaudara }\end{array}$ & $\begin{array}{c}\text { Anak ke 3 dari 3 } \\
\text { bersaudara }\end{array}$ & $\begin{array}{c}\text { Anak ke 1 dari 2 } \\
\text { bersaudara }\end{array}$ \\
\hline Pekerjaan & Magang & PNS & Pegawai Honorer \\
\hline Agama & Islam & Islam & Islam \\
\hline Suku Bangsa & Betawi & Makassar & Minangkabau \\
\hline Pendidikan Terakhir & S1 & D1 & S1 \\
\hline
\end{tabular}

Teknik pengumpulan data pada penelitian ini akan menggunakan observasi dan in depth interview atau wawancara mendalam. Teknik analisis data pada penelitian ini menggunakan model interaktif menurut Miles \& Huberman terdiri atas empat tahapan (Herdiansyah, 2010) :

1. Pengumpulan Data

Proses pengumpulan data dilakukan ketika peneliti melakukan studi preeliminary (melakukan pendekatan dengan subjek, wawancara dan observasi).

2. Reduksi Data

Reduksi data merupakan proses penggabungan dan penyeragaman segala bentuk data yang diperoleh mernjadi suatu tulisan yang akan dianalisis. Hasil wawancara dan hasil observasi diubah menjadi sebuah bentuk tulisan yang sesuai dengan formatnya masing-masing. 
3. Display Data

Pada tahap display data, berisi mengenai pengolahan data setengah jadi yang sudah tertata dalam bentuk tulisan yang memiliki alur tema yang jelas, dimana tema-tema tersebut sudah dikelompokkan dan dikategorikan, lalu dipecah menjadi subtema yang diakhiri dengan pemberian kode dari subtema tersebut sesuai dengan verbatim wawancara yang telah dilakukan.

4. Verifikasi Data

Terdapat tiga tahapan yang perlu dilakukan dalam tahap verifikasi data. Pertama, menguraikan subkategori tema dalam tabel kategorisasi dan pengkodean beserta dengan quote verbatim wawancaranya. Kedua, menjelaskan hasil temuan penelitian dengan menjawab pertanyaan penelitian berdasarkan teori dari fenomena penelitiannya. Ketiga, membuat kesimpulan dari hasil temuan yang diajukan.

\section{HASIL DAN PEMBAHASAN}

Berdasarkan hasil wawancara yang dilakukan peneliti kepada para subjek beserta informannya, berikut gambaran proses grieving para subjek:

Tabel 2. Gambaran Inter Kasus Proses Grieving pada Setiap Subjek

\begin{tabular}{|c|c|c|c|}
\hline $\begin{array}{c}\text { Empat Tugas } \\
\text { Proses Berduka }\end{array}$ & Subjek NA & Subjek KT & Subjek CT \\
\hline $\begin{array}{l}\text { Tugas 1: } \\
\text { Menerima } \\
\text { Kenyataan Atas } \\
\text { Kehilangan. }\end{array}$ & $\begin{array}{l}\text { Sulit percaya ketika } \\
\text { mendengar kabar } \\
\text { bahwa ibunya telah } \\
\text { tiada akibat terpapar } \\
\text { virus COVID-19, } \\
\text { dikarenakan pandemi } \\
\text { sehingga subjek } \\
\text { beserta keluarga tidak } \\
\text { dapat melakukan } \\
\text { ritual pemakaman } \\
\text { seperti biasanya, } \\
\text { hanya bisa melihat } \\
\text { proses pemakaman } \\
\text { almarhum ibunya } \\
\text { dari jauh. Hal ini } \\
\text { membuat ia } \\
\text { merasakan kesedihan } \\
\text { yang sangat dalam } \\
\text { dan juga rasa } \\
\text { bersalah karena tidak } \\
\text { dapat melakukan } \\
\text { ritual pemakaman } \\
\text { yang sepantasnya. } \\
\text { Setelah 100 hari } \\
\text { setelah kepergian } \\
\text { ibunya, baru dapat } \\
\text { menerima kenyataan } \\
\text { atas kepergian } \\
\text { ibunya. }\end{array}$ & $\begin{array}{l}\text { Menunjukkan perasaan } \\
\text { sedih dan terdapat } \\
\text { sensasi fisik yaitu lemas } \\
\text { dan rasa sakit di badan. } \\
\text { Subjek tidak merasakan } \\
\text { perasaan tidak percaya } \\
\text { dikarenakan, almarhum } \\
\text { ibu memiliki riwayat } \\
\text { penyakit kanker. Hal ini } \\
\text { membuat subjek } \\
\text { memiliki waktu untuk } \\
\text { mempersiapkan diri } \\
\text { ketika menghadapi } \\
\text { kepergian ibunya. } \\
\text { Merasa bersalah atas } \\
\text { kepergian ibunya di era } \\
\text { pandemi, karena ia tidak } \\
\text { dapat mendampingi } \\
\text { ibunya sampai akhir } \\
\text { waktunya. }\end{array}$ & $\begin{array}{l}\text { Sulit menerima } \\
\text { kenyataan atas } \\
\text { kepergian ayahnya. } \\
\text { Merasa tidak percaya, } \\
\text { kesal, sedih, dan marah } \\
\text { atas kepergian ayahnya } \\
\text { yang mendadak. } \\
\text { Membutuhkan waktu } \\
\text { lebih dari enam bulan } \\
\text { setelah kepergian } \\
\text { ayahnya, subjek } \\
\text { menerima kenyataan } \\
\text { atas kepergian ayahnya. }\end{array}$ \\
\hline
\end{tabular}




\begin{tabular}{|c|c|c|c|}
\hline $\begin{array}{c}\text { Empat Tugas } \\
\text { Proses Berduka }\end{array}$ & Subjek NA & Subjek KT & Subjek CT \\
\hline $\begin{array}{l}\text { Tugas 2: } \\
\text { Mengatasi Rasa } \\
\text { Sakit dan Kesedihan } \\
\text { Atas Kehilangan. }\end{array}$ & $\begin{array}{l}\text { Subjek NA mengatasi } \\
\text { rasa sakit dan } \\
\text { sedihnya, dengan } \\
\text { beribadah, ketika } \\
\text { beribadah perasaan } \\
\text { sedih subjek NA } \\
\text { menjadi teralihkan. }\end{array}$ & $\begin{array}{l}\text { Subjek KT mengatasi } \\
\text { rasa sakit dan sedihnya } \\
\text { dengan cara } \\
\text { membicarakannya } \\
\text { dengan teman-temannya } \\
\text { melalui video-call. }\end{array}$ & $\begin{array}{l}\text { Subjek CT mengalami } \\
\text { kesulitan dalam } \\
\text { menghadapi rasa } \\
\text { sedihnya dikarenakan } \\
\text { adanya beberapa } \\
\text { hambatan. Namun } \\
\text { setelah beberapa waktu } \\
\text { berlalu subjek CT } \\
\text { berhasil rasa sakit dan } \\
\text { kesedihannya melalui } \\
\text { bekerja dan juga } \\
\text { meyakinkan diri bahwa } \\
\text { ia mampu melewati rasa } \\
\text { sedih yang ia alami. }\end{array}$ \\
\hline $\begin{array}{l}\text { Tugas } 3 \text { : } \\
\text { Beradaptasi pada } \\
\text { Lingkungan Baru. }\end{array}$ & $\begin{array}{l}\text { Subjek NA } \\
\text { mengalami } \\
\text { perubahan pandangan } \\
\text { hidup setelah } \\
\text { kepergian ibunya. } \\
\text { Subjek NA } \\
\text { memandang bahwa ia } \\
\text { hanya perlu berserah } \\
\text { diri pada Yang Maha } \\
\text { Kuasa, selain itu } \\
\text { subjek NA juga } \\
\text { mengalami } \\
\text { perubahan dalam } \\
\text { spiritual nya dimana } \\
\text { ia menjadi lebih rajin } \\
\text { beribadah setelah } \\
\text { kepergian ibunya }\end{array}$ & $\begin{array}{l}\text { Semenjak kepergian } \\
\text { ibunya akibat terpapar } \\
\text { virus COVID-19, subjek } \\
\text { KT kesulitan untuk } \\
\text { pergi keluar rumah } \\
\text { karena takut akan } \\
\text { terpapar virus COVID- } \\
\text { 19, selain itu subjek KT } \\
\text { juga mengalami } \\
\text { perubahan pada } \\
\text { spiritualnya dimana ia } \\
\text { menjadi lebih rajin } \\
\text { dalam beribadahnya. }\end{array}$ & $\begin{array}{l}\text { Subjek CT beradaptasi } \\
\text { pada lingkungan tanpa } \\
\text { ayahnya dengan } \\
\text { mengalami beberapa } \\
\text { perubahan. Kepergian } \\
\text { ayahnya yang mendadak } \\
\text { dan terpapar virus } \\
\text { COVID-19, membuat } \\
\text { subjek CT menjadi } \\
\text { sangat takut dengan } \\
\text { virus COVID-19, subjek } \\
\text { CT juga menjadi } \\
\text { cenderung lebih mudah } \\
\text { tersinggung, dan } \\
\text { emosinya mudah } \\
\text { berubah, selain itu } \\
\text { kepergian ayahnya yang } \\
\text { mendadak dan juga } \\
\text { keadaan pandemi } \\
\text { membuat subjek CT } \\
\text { mengalami perubahan } \\
\text { finansial, subjek CT dan } \\
\text { keluarga menjadi lebih } \\
\text { berhemat dalam } \\
\text { keuangannya. }\end{array}$ \\
\hline $\begin{array}{l}\text { Tugas 4: } \\
\text { Mencari dan } \\
\text { Mempertahankan } \\
\text { Hubungan dengan } \\
\text { Almarhum Selagi } \\
\text { Maju Terus Dalam } \\
\text { Kehidupan. }\end{array}$ & $\begin{array}{l}\text { Ketika subjek NA } \\
\text { merindukan } \\
\text { almarhum ibunya } \\
\text { terkadang subjek NA } \\
\text { Kembali lagi pada } \\
\text { tugas kedua dimana } \\
\text { ia mengatasi rasa } \\
\text { sakit dan sedihnya, } \\
\text { namun di lain waktu } \\
\text { Ketika subjek NA } \\
\text { merindukan ibunya, } \\
\text { subjek NA meyakini }\end{array}$ & $\begin{array}{l}\text { Subjek sampai saat ini } \\
\text { masih merindukan } \\
\text { almarhum ibunya, } \\
\text { namun subjek KT sudah } \\
\text { lega dalam melepas } \\
\text { kepergian ibunya, } \\
\text { subjek KT menganggap } \\
\text { bahwa almarhum ibunya } \\
\text { telah berjuang untuk } \\
\text { melawan sakit dalam } \\
\text { waktu yang cukup lama, } \\
\text { saat ini almarhum } \\
\end{array}$ & $\begin{array}{l}\text { Saat ini subjek CT } \\
\text { sudah merasa lebih baik } \\
\text { dan sudah bisa } \\
\text { melepaskan dengan baik } \\
\text { kepergian almarhum } \\
\text { ayahnya. Subjek CT } \\
\text { menyatakan bahwa } \\
\text { selama hidupnya yang ia } \\
\text { tahu bahwa ayahnya } \\
\text { selalu bekerja untuk } \\
\text { keluarganya tanpa } \\
\text { mengenal lelah, } \\
\end{array}$ \\
\hline
\end{tabular}




\begin{tabular}{|c|l|l|l|}
\hline $\begin{array}{c}\text { Empat Tugas } \\
\text { Proses Berduka }\end{array}$ & \multicolumn{1}{|c|}{ Subjek NA } & \multicolumn{1}{c|}{ Subjek KT } & \multicolumn{1}{c|}{ Subjek CT } \\
\hline & $\begin{array}{l}\text { dirinya sendiri bahwa } \\
\text { dirinya baik-baik saja } \\
\text { karena almarhum } \\
\text { ibunya tetap } \\
\text { menjaganya dari atas } \\
\text { sana. }\end{array}$ & $\begin{array}{l}\text { ibunya sudah bisa } \\
\text { istirahat dengan tenang } \\
\text { setelah melalui } \\
\text { perjuangan yang } \\
\text { panjang. }\end{array}$ & $\begin{array}{l}\text { sekarang almarhum } \\
\text { ayahnya dapat } \\
\text { beristirahat dengan } \\
\text { tenang. Pada waktu } \\
\text { tertentu, subjek CT } \\
\text { merindukan ayahnya, ia } \\
\text { akan mengenang } \\
\text { ayahnya dengan } \\
\text { membicarakannya } \\
\text { bersama ibu dan } \\
\text { adiknya. }\end{array}$ \\
\hline
\end{tabular}

\section{Tugas 1: Untuk menerima kenyataan atas kehilangan}

Respons ketiga subjek secara umum ketika mendapat kabar kepergian salah satu orangtuanya, di antaranya adalah tidak percaya, sedih, kaget, dan merasakan sakit fisik seperti tidak bisa bergerak atau lemas. Pada subjek CT juga diikuti dengan emosi marah dan kesal. Waktu yang dibutuhkan oleh ketiga subjek dalam menerima kenyataan atas kehilangan almarhum berbeda-beda. Pada subjek NA, waktu yang ia butuhkan untuk menerima kenyataan bahwa ibunya sudah pergi dan tidak akan kembali lagi adalah sebulan, sedangkan subjek KT membutuhkan waktu yang lebih singkat, dan pada subjek CT, waktu yang dibutuhkan untuk menerima kenyataan bahwa ayahnya telah pergi dan tidak akan kembali terjadi setelah ia menyaksikan pemakaman ayahnya.

Pada tugas berduka, Worden menyatakan bahwa menerima kenyataan atas kehilangan membutuhkan dukungan tambahan seperti menghadiri pemakaman (Shear, 2012). Hal ini sejalan dengan data yang didapat dari wawancara yang dilakukan dengan subjek CT dan juga informan subjek CT, bahwa ia menerima kenyataan atas kepergian ayahnya setelah menghadiri pemakaman ayahnya. Pada subjek NA mengalami kesulitan dalam menerima kenyataan atas kehilangan ibunya dikarenakan ibunya meninggal secara mendadak. Salah satu faktor yang memengaruhi proses grief adalah tipe kematian almarhum. Pada almarhum ibu subjek NA meninggal secara mendadak. Tipe kematian ini memberikan dampak negatif yang lebih tinggi daripada kematian yang sudah diprediksi karena tidak ada waktu yang cukup untuk mempersiapkan kematian dan melakukan perpisahan [8]. Selanjutnya pada almarhum ibu subjek KT memiliki tipe kematian yang sudah diprediksi. Hal ini didapat berdasarkan data yang menjelaskan bahwa almarhum ibu subjek KT memiliki riwayat penyakit kanker, sehingga subjek KT dan keluarga sudah mempersiapkan diri sebelumnya ketika hal terburuk terjadi.

\section{Tugas 2: Untuk Mengatasi Rasa Sakit dan Kesedihan Atas Kehilangan}

Pada tugas kedua Worden, yaitu menghadapi rasa sakit dan kesedihan atas kehilangan, ketiga subjek dalam proses menjalaninya mengalami beberapa hambatan. Pada ketiga subjek memiliki satu cara yang sama dalam mengatasi rasa sakit dan sedihnya yaitu pada saat ketiga subjek bekerja, pekerjaan yang mereka miliki membantu proses mereka dalam menyelesaikan tugas kedua Worden, karena 
saat bekerja, fokus mereka atas kesedihannya menjadi teralihkan untuk fokus dalam pekerjaannya.

Menurut Worden terdapat beberapa mediator yang berkemungkinan memengaruhi proses grief, di antaranya adalah kelekatan. Pada subjek NA dan KT memiliki hubungan sangat dekat dengan almarhum ibunya sehingga kedua subjek mengalami rasa sakit dan sedih yang luar biasa ketika kehilangan ibunya. Adapun cara yang dilakukan oleh subjek NA dalam mengatasi rasa sakit dan kesedihannya adalah dengan meyakinkan dirinya sendiri bahwa ia bisa melewati masa-masa kelam tersebut, dan subjek NA juga mengalihkan kesedihannya dengan cara beribadah. Pada subjek KT juga ditemukan cara yang sama dalam mengatasi rasa sakit dan kesedihannya, namun pada subjek KT juga didukung oleh adanya dukungan yang ia rasakan dari kerabatnya.

Berbeda dengan kedua subjek di atas, subjek CT memilih untuk berdiam diri dan mengalihkan rasa sedih dan sakitnya dengan fokus merawat adiknya yang pada saat itu dinyatakan positif COVID-19 sebagai cara mengatasi rasa sedih dan sakitnya. Pada subjek CT membutuhkan waktu yang lebih lama dalam menyelesaikan tugasnya, karena caranya yang berdiam diri membuat ia menahan perasaan yang ia rasakan. Mediator lain yang memengaruhi proses grief yaitu adanya stress konkuren yaitu faktor stress yang berturut-turut datang dalam kehidupan yang berduka. Mediator ini terjadi pada subjek CT. Sebulan setelah kepergian ayahnya, subjek CT juga mendapatkan kabar buruk bahwa adiknya positif COVID-19. Hal ini juga menghambat subjek CT dalam menghadapi dan mengatasi rasa sakit dan sedihnya karena subjek CT lebih memilih untuk mengabaikan perasaan sakit dan sedihnya daripada menghadapinya. Alasan subjek CT mengabaikan perasaannya karena ia merasa bahwa setelah ayahnya pergi, ia memiliki rasa tanggung jawab yang lebih besar untuk menjaga adik dan ibunya. Hal ini sejalan dengan pernyataan pada penelitian Putri pada tahun 2019 yang menjelaskan bahwa pada masa ini, dewasa awal mulai menerima dan membawa tanggung jawab yang lebih berat.

\section{Tugas 3: Untuk Beradaptasi pada Lingkungan Baru}

Pada ketiga subjek, setelah kepergian orangtuanya, mereka megalami perubahan dalam hidupnya. Pada subjek NA, perubahan yang terjadi dalam hidupnya adalah pandangannya mengenai kehidupan. Ia menjadi lebih pasrah mengenai kehidupannya, ia menyatakan bahwa merencanakan sesuatu dalam kehidupan tidak ada gunanya, karena pada akhirnya semua tergantung pada Yang Maha Kuasa.

Perubahan pandangannya ini menjadikan subjek NA saat ini, tidak memiliki rencana apapun pada kehidupan kedepannya. Selain itu terdapat perubahan lain pada subjek NA yaitu perubahan pada sisi spiritualnya, sebelumnya pada tugas kedua subjek NA mengatasi rasa sakit dan kesedihannya dengan cara beribadah, hal ini menjadi salah satu perubahan yang terjadi. Subjek NA menjadi lebih sering beribadah, ketika ia merasa sedih, subjek NA akan mengalihkan pikirannya dengan beribadah.

Sedangkan pada subjek KT dan CT, kepergian orangtuanya di era pandemi ini memberikan dampak emosional pada kedua subjek. Dampak emosional yang terlihat pada kedua subjek merupakan adanya trauma dan perasaan takut atas kejadian yang telah menimpa kedua subjek. Trauma tersebut dijelaskan pada perilaku yang 
ditunjukkan oleh kedua subjek terhadap bagaimana menangggapi pandemi ini. Perilaku tersebut diantaranya, kedua subjek mengakui bahwa mereka takut akan virus COVID-19, sehingga kedua subjek menjadi sangat berusaha dalam menaati protokol kesehatan. Perasaan takut yang ditunjukkan kedua subjek menjadi berlebihan ketika, kedua subjek menolak untuk keluar sama sekali dari rumah, mengalami kenaikan emosi ketika ada salah satu anggota keluarga yang keluar rumah, mencuci tangan berlebihan sehingga kulit menjadi kering, dan juga cenderung mengalami naik turun emosi yang cepat.

\section{Tugas 4: Untuk Mencari dan Mempertahankan Hubungan dengan Almarhum Selagi Maju Terus dalam Kehidupan}

Pada tugas keempat Worden, yaitu mencari dan mempertahankan hubungan dengan Almarhum selagi maju terus dalam kehidupan, ketiga subjek menunjukkan bahwa saat ini mereka sudah merasa lebih baik. Persamaan yang terdapat pada ketiga subjek adalah mereka telah merelekan kepergian orangtuanya, mereka memiliki pandangan bahwa saat ini orangtuanya telah beristirahat dengan tenang di atas sana. Selain itu juga cara para subjek dalam mempertahankan hubungan mereka dengan almarhum orangtuanya adalah dengan cara berusaha dalam meneruskan hal-hal baik yang selama ini almarhum orangtuanya telah ajarkan kepada mereka.

Perbedaan yang terdapat pada setiap subjek adalah tempat mereka menyimpan kenangan mengenai almarhum dalam hidupnya. Pada subjek NA, ia menyatakan bahwa ketika ia merasa merindukan almarhum ibunya ia akan mengingat ibunya dengan cara datang ke makam almarhum ibunya atau melihat foto-foto ibunya yang terdapat pada telepon genggam ibunya. Berbeda dengan subjek NA, subjek KT menyatakan bahwa ketika ia merasakan rindu kepada almarhum ibunya, ia akan membicarakan rasa rindunya dengan kerabat dekatnya. Sedangkan pada subjek CT, ketika ia merasakan rindu terhadap ayahnya, ia akan membicarakan mengenai perilaku almarhum ayahnya yang ia ingat kepada ibu dan adiknya.

\section{SIMPULAN DAN SARAN}

\section{Simpulan}

Penelitian ini menunjukkan bahwa walaupun berada di era pandemi (tidak bisa berkomunikasi dengan langsung dengan orang-orang terdekat, tidak dapat menyaksikan pemakaman almarhum, tidak dapat mendampingi almarhum pada terakhir kalinya, bahkan terkena musibah lain seperti anggota keluarga lain juga terkena COVID atau ayah meninggal seminggu setelah ibu meninggal terkena COVID), seluruh subjek yang berada dalam masa dewasa awal mampu menyelesaikan proses grieving. Terdapat beberapa hal yang membantu mereka seperti adanya keyakinan dan kemauan pada diri sendiri bahwa mereka mampu menghadapi musibah yang terjadi dalam hidup mereka, selain itu ketika dewasa awal tidak dapat berkomunikasi langsung dengan orang-orang terdekatnya, mereka mengalihkannya dengan beribadah kepada Allah, dan juga pada dewasa awal ini memiliki pekerjaan sehingga fokus mereka atas kesedihannya menjadi teralihkan untuk fokus bekerja. 
Kehilangan orangtua di era pandemi menyebabkan dampak emosional bagi subjek. Subjek dapat mengalami trauma dan takut dalam menghadapi pandemi ini. Namun, ada subjek yang dalam proses menyelesaikan tugas ketiga Worden, mengalami perubahan pada perilakunya, karena orang tua meninggal akibat terpapar virus COVID-19, ia menjadi takut dengan pandemi ini. Perilaku takutnya ditunjukkan pada saat ia menjadi sangat mematuhi protokol kesehatan yang ada, dan subjek enggan untuk keluar rumah kecuali terdapat masalah yang penting. Perubahan perilaku tersebut dapat disertai dengan emosi yang berubah-ubah, cenderung lebih mudah tersinggung dan lebih mudah untuk marah. Ia akan marah jika anggota keluarga lainnya keluar rumah. Emosi subjek cenderung berubah-ubah merupakan dampak dari cara subjek yang memilih untuk menahan emosinya saat merasakan kesedihan.

\section{Saran}

Pada penelitian selanjutnya, diharapkan tidak hanya meneliti mengenai grieving, namun menggunakan variabel lain sehingga dapat menjadi kajian baru terkait dampak dari pandemik COVID-19. Selain itu pada penelitian ini, data diambil pada Desember 2020, pada saat sedang pandemik sehingga peneliti tidak dapat melakukan pengambilan data wawancara secara langsung dengan subjek. Sehingga pada penelitian selanjutnya, diharapkan dapat melakukan pengambilan data penelitian secara langsung tatap muka dengan subjek agar proses observasi yang dilakukan dapat dilaksanakan dengan baik.

a. Penyintas

Bagi para penyintas diharapkan dengan adanya penelitian ini dapat membantu dalam menjalani proses grieving dengan cara yang sesuai di era pandemi COVID19.

b. Kerabat Penyintas

Bagi kerabat penyintas diharapkan dengan adanya penelitian ini, dapat memberikan gambaran mengenai bagaimana memberikan dukungan yang sesuai untuk para penyintas di era pandemi COVID-19.

\section{REFERENSI}

Arslan, S. B., \& Buldukoglu, K. (2018). Grieving Support Programs Implemented to Reduce the Effects of Grieving on Family. Current Approaches in Psychiatry, 11(3), 402-417. doi:10.18863/pgy.444297

Herdiansyah, H. (2010). Metode Penelitian Kualitatif untuk Ilmu-ilmu Sosial. Jakarta: Salemba Humanika.

Mash , H. B., Fullerton , C. S., Shear , K. M., \& Ursano, R. J. (2015). Complicated Grieving \& Depression in Young Adults: Personality \& Relationship Quality. The Journal of Nervous and Mental Disease, 539-543. https://doi.org/10.1097/NMD.0000000000000155

Overvad, A. T., \& Wagoner, B. (2019). Grieving After Suicide: A Study of Taboo and Metaphor. Culture \& Psychology, 1-15. 
Prigerson, H. G., Boelen, P. A., Xu, J., Smith, K. V., Maciejewski, P. K. (2021). Validation Of The Nwe DSM-5-TR Criteria For Prolonged Grieving Disorder and The PG-13-Revised (PG-13-R) Scale. World Psychiatry, 20(1), 96-106. https://doi.org/10.1002/wps.20823

Singer, J., \& Spiegel , J. A. (2020, June 1). Preloss Grieving in Family Members of COVID-19 Patients: Recommendations for Clinicians and Researchers. Psychological Trauma: Theory, Research, Practice, and Policy, S90-S93. doi:http://dx.doi.org/10.1037/tra0000876

Shear, M. K. (2012). Grieving and Mourning Gone Awry: Pathway and Course of Complicated Grief. Dialogues in Clinical Neurocience, 14, 119-128. https://doi.org/10.31887/DCNS.2012.14.2/mshear

Shoemaker, J. B. (2019 ). Beneficial Mourning by Inmates Who Have Lost a Significant Person. Theses and Dissertations (Comprehensive)

Worden, J. W. (2018). Grieving Counseling and Grieving Therapy Fifth Edition. New York: Springer Publishing Company. 